\title{
The Effect of Fundamental Determinants on Voluntary Disclosure of Financial and Nonfinancial Information: The Case of Tehran Stock Exchange
}

Abdolreza Ghasempour*and Mohd Atef bin MdYusof

Department of Accounting, Universiti Utara Malaysia, Sintok, Kedah, Malaysia

\begin{abstract}
Recent tendency of businesses towards voluntary disclosure has improved the quality of financial reporting High-quality financial reporting helps users of financial information trust the business, and thus, creates value for the business. The present study divided voluntary disclosure in two groups of financial and non-financial information and investigated the effects of fundamentals on voluntary disclosure by businesses. The population was composed of 65 companies listed on the Tehran Stock Exchange from 2005 to 2012. The hypothesis testing results showed that firm size, business complexity, earnings volatility, and firm value had a significant and positive impact on voluntary disclosure whereas financial leverage had a significant and negative impact on voluntary disclosure, while no relationship was observed between voluntary disclosure and financial performance.
\end{abstract}

Keywords: Voluntary disclosure; Fundamental variables; Financial reporting; Financial performance

\section{Introduction}

With the development of privatization and economic growth, shareholding grows to become a public trend. The increasing number of shareholders and active institutions in the financial sector, including but not limited to investment companies, rating agencies, mutual funds, brokerage firms, and investment advisory firms, necessitates broad studies on finance and accounting. Due to the sudden changes in the stock market structure, policy makers need to enact laws and regulations for companies to minimize the possibility of misrepresentation and encourage disclosure of information. These policies prepare companies for global stock exchange markets.

Among the most important areas are studies investigating information disclosure by companies as well as investor behavior, attempting to identify the fundamentals underlying different investor decision making under equal circumstances. Scholars, analyzers, and empiricists including Verrecchia [1], Darrough and Stoughton [2], and Hughes [3] have concerned themselves with the incentives of companies for voluntary disclosure. Recent decades have observed numerous researchers trying to identify variables defining the behavior of shareholders and other stakeholders. The present study is an attempt to further the mentioned studies.

Global investors and creditors base their decisions on the information reported in different economic, financial, and nonfinancial reports provided by stock exchange enlisted companies. Prior to decision-making concerning investment on a specific share, investors and creditors also take into account profitability, financial particulars, and nonfinancial particulars including staff information, Board Members" salary and benefits, and internal stock transfers. Therefore, voluntary disclosure, undertaken by many companies enlisted on world's most credible stock exchange markets, is a logical development of basic information disclosure in annual financial reports, necessarily reflecting the information pertaining to the economic realities of a company in a meaningful, transparent, and comparable manner. In Iran, with the enactment of Internal Auditing By-Law as well as the ByLaw of Corporate Governance the first steps have been taken towards voluntary disclosure on the part of companies. However, traditional and not so comprehensive and detailed disclosure of general information in the reports of Board of Directors or exclusive websites of companies, and verylittle in notes accompanying financial reports are still the only sources for optional and voluntary disclosure of information by Iranian companies.

Studies on voluntary disclosure have been conducted in many developed countries. In order for protecting the interests of public investors and the other parties in the market, a legal and efficient system of disclosure needs to be devised. With the development of securities market in many developed countries including the US (10$\mathrm{K}$ Act) or East Asian countries such as China, a large amount of legal information concerning public disclosure of information has been published by the enlisted companies on Stock Exchange Markets for public consideration. Yet, scholars, analysts, and empiricists have regrettably not considered specific laws focusing on the incentives of firms for voluntary disclosure. Analytical studies indicate the fact that how competition influences disclosure levels [1,2], and how disclosure is employed as a signal for firm's value [3]. The present study is specifically concerned with the voluntary disclosure of information on the intellectual capital and knowledge assets in Tehran Stock Exchange. This approach fills out some of the mentioned research gaps and further develops the related literature in a global level.

\section{Theoretical framework and review of the related literature}

Disclosure, in its simple and general sense, is defined as transferring and presenting economic information associated with the financial status and performance of firms, whether financial or nonfinancial, quantitative or in other forms. If it is made compulsory through sources

*Corresponding author: Abdolreza Ghasempour, Department of Accounting Universiti Utara Malaysia, Sintok, Kedah, Malaysia, Tel: 604-928 5656; Fax: 604 928 5220; E-mail: reza52_gh@yahoo.com

Received December 18, 2013; Accepted January 29, 2014; Published February 06, 2014

Citation: Ghasempour A, MdYusof MA (2014) The Effect of Fundamental Determinants on Voluntary Disclosure of Financial and Nonfinancial Information: The Case of Tehran Stock Exchange. J Account Mark 3: 108. doi: 10.4172/21689601.1000108

Copyright: ( 2014 Ghasempour A, et al. This is an open-access article distributed under the terms of the Creative Commons Attribution License, which permits unrestricted use, distribution, and reproduction in any medium, provided the original author and source are credited. 
of law, this disclosure is referred to as "Mandatory Disclosure", and if it is not mandated by any specific regulation, it is considered "Voluntary Disclosure". Furthermore, disclosure implies presenting a minimum amount of information in firm reports, based on which a reasonable evaluation of the firm's relative risks and value can be drawn and which can assist information users in this regard [4].

Both traditional (mainly monetary) and voluntary disclosure (mainly non-monetary) are efficient sources of information for stakeholders. Empirical studies on voluntary disclosure maintain a rather long history, commenced by Cerf and followed by a plethora of complementarystudies concerned with investigating the influence of other company features on disclosure, including size, type of stock exchange admission, leverage, and administrative structure.

Expenses for development and collection of detailed information can be rather higher for small companies compared to large corporations. As, in large corporations, the mentioned information has already been developed for internal reporting to the administration, therefore, its disclosure shall not incur extra expenses Owusu-Ansah [4] also maintain that production and dissemination of information is a costly activity and larger corporations probably have the required resources and expert staff for the dissemination of financial reports with high disclosure levels and consequently higher compliance with the disclosure regulations. It can thus be concluded that disclosure costs per unit are reduced and as a result large corporations disclose higher amounts of information. As quoted by Owusu-Ansah [4], Stigler [5] considering the available economic facilities for information production and storage, large corporations are inclined to spend more resources for information production, and disclosure of information is higher in large corporations rather than small companies. Stigler [5] found out that the response to larger negative earnings is mostly obtained through voluntary disclosure by companies. Many studies today indicate the effects of disclosure on the cost of capital [6] and the cost of debt [7]. There are also numerous studies on corporate governance and disclosure [8-13]. In Iran, it seems, there are significant research gaps in this area. Little research has been conducted on the subject under discussion in Iran, with each one addressing only small portions of voluntary disclosure literature [14-17]. Taking into account different stakeholder groups, the present study has attempted to further develop the literature in many aspects nationally and in a few aspects worldwide.

O'Dwyer [18] investigated first-hand the incentives of directors for social information disclosure in annual reports. The results showed that directors maintain that social pressures necessitate the accountability of companies and disclosure of information in annual reports is deemed as a gesture of redeeming their legitimacy.

Another study which investigated the influence of governance, corporate governance mechanisms, and firm-specific characteristics on the voluntary disclosure of Shanghai Stock Exchange listed companies. The results indicated that sole proprietorship, existence of an audit committee, firm size, and leverage are significantly related to voluntary disclosure. Their findings moreover indicated an understanding of disclosure behavior in state-owned entities during the privatization process in China. This study intends to investigate different governance variables and firm-specific characteristics within the framework of Stakeholder Theory.

In Australia, Deegan et al. [19] utilized Legitimacy Theory to explain the changes in disclosure of environmental reports by enterprises for periods in which authorities, including the government and
Environmental Protection Organization, emphasized compliance with environmental protection regulations. The results portrayed that during the years companies were pressured to comply with environmental protection regulations, their disclosure tended to be more desirable and comprehensive in this regard, as compared to the other years. They also found out that regulatory requirements concerning environmental protection coerces enterprises to turn to environmental disclosure. It seems that business entities struggle to retain their legitimacy via voluntary disclosure when they have violated a social contract.

Deegan et al. [19] conducted a study on the methods of social and environmental disclosure employed by Australian companies. The results supported the legitimacy-seeking incentives of directors of socio-environmental information-disclosing companies.

In another study, Kashanipoor et al. [17] investigated the relationship between voluntary disclosure of a company and the number of its non-executive directors. Their sample was composed of 239 companies. Their disclosure checklist listed 71 items. Their results showed that there was not a significant relationship between voluntary disclosure and the percentage of non-executive directors on the Board.

Sajadi et al. [15] studied the relationship between five nonfinancial characteristics of Tehran Stock Exchange listed companies and the quality of their financial reporting. To measure the financial reporting quality, an index was employed containing 155 items, following Iran Accounting Standards and other disclosure pertaining regulations, to investigate possiblerelationships between the firm size, type of auditing institute, type of industry, ownership structure, and company age, and financial reporting quality, using models of multiple regression. The results showed that firm size, company age, and type of industry maintained significant positive relationships while ownership structure had a negative relationship with the financial reporting quality, whereas the relationship between type of auditing institute and financial reporting quality was not significant.

In their applied descriptive-survey study, Yazdi et al. [14] investigated the feasibility of social reporting by Tehran Stock Exchange listed companies, collecting the data using questionnaires. They concluded that social reporting is not well-received for a couple of reasons, namely: absence of a proper accounting information system, reluctance of directors to disclose company's social costs, absence of legal standards, and high costs of developing social reports. They also provided evidences indicating that directors are more inclined to disseminate measures they have taken concerning employee welfare and health, charity, and environmental protection.

In addition to the above-gone examples, many scholars have struggled in the recent decades to identify the defining variables in explaining shareholder behavior and other stakeholders. The present study is an attempt to further develop these studies.

\section{Methodology}

This is a descriptive-library study in terms of data collection, an applied study in terms of the objective, and concerning hypothesis testing, this study is classified as correlational, adopting a deductiveinductive approach, and of causal-comparative type. In terms of sampling method it is a semi empirical study. Initially the population was studied, including Tehran Stock Exchange listed companies who have been active from March 2005 through to 2012. Of course, for mean calculation for some of the variables, the period was extended to include March 2002. Then the companies lacking the required characteristics were excluded, and the sample was ultimately selected from among the 
remaining companies. The designated variables were later on extracted from different information sources, databases, and financial reports of the sample companies, and consequently the hypotheses were tested.

\section{Sample and sampling procedure}

The population of the present study was Tehran Stock Exchange listed companies who have been active from March 2005 through to 2012. Approximately 330 companies have been active on Tehran Stock Exchange since March 2002. However, for mean calculation of some variables, the period has been extended to include March 2002, adding up to a number of 320 active companies. Tehran Stock Exchange Organization was the research location. Research period is from March 2002 to March 2012. As for hypothesis testing, the companies were selected as sample only if:

1. The company is not in the financial intermediation industry, as the capital structure of these institutes are different

2. The company has been enlisted on Tehran Stock Exchange since March 2002

3. The company's ticker symbol does not suffer a significant halt (i.e. does not suffer a halt of more than 3 months on the stock market board)

\section{The company's data are available}

Having considered the above-gone conditions, the population shrank to 182 companies, out of which 65 companies were randomly selected and analyzed as the sample. The pertinent data was investigated for a 7 year period, i.e. a total of 455 observations (year-company) were tested for hypothesis testing.

$$
n \geq \frac{N Z_{a / 2}^{2} \times P(1-P)}{(N-1) \epsilon^{2}+Z_{\frac{a}{2}}^{2} \times P(1-P)}=65
$$

\section{Research hypotheses}

To achieve the objectives, the research hypotheses are addressed in two separate divisions.

\section{Primary hypotheses}

A. There is a significant relationship between company fundamentals and voluntary disclosure offinancial information

B. There is a significant relationship between company fundamentals and voluntary disclosure ofnonfinancial information

\section{Secondary hypotheses group 1 :}

A1: There is a significant relationship betweenthe company's market value and levels ofvoluntary disclosure of financial information;

A2: There is a significant relationship between the firm size and levels of voluntary disclosureof financial information;

A3: There is a significant relationship between access to growth opportunities and levels ofvoluntary disclosure of financial information;

A4: There is a significant relationship between complexity of business and levels of voluntarydisclosure of financial information;

A5: There is a significant relationship between financial performance and levels of voluntarydisclosure of financial information;

A6: There is a significant relationship between earnings volatility and levels of voluntarydisclosure of financial information;

\section{Secondary hypotheses group 2:}

B1: There is a significant relationship betweenthe company's market value and levels ofvoluntary disclosure of nonfinancial information;

B2: There is a significant relationship between the firm size and levels of voluntary disclosureof nonfinancial information;

B3: There is a significant relationship between access to growth opportunities and levels ofvoluntary disclosure of nonfinancial information;

B4: There is a significant relationship between complexity of business and levels of voluntarydisclosure of nonfinancial information;

B5: There is a significant relationship between financial performance and levels of voluntarydisclosure of nonfinancial information;

B6: There is a significant relationship between earnings volatility and levels of voluntarydisclosure of nonfinancial information;

\section{Research variables and how they are calculated}

Research variables are listed below as employed in the first section:

Voluntary disclosure index (VolDiscT): Voluntary disclosure is defined as disclosure of information by companies besides what mandated by Iranian Accounting Standards, including the entire financial and nonfinancial items, not enlisted on the Adequacy of Disclosure Checklist [20].

Different studies in the pertinent literature, have adopted various criteria and scores for measuring voluntary disclosure: management forecasts, managerial speeches, self-constructed scores, and standard scores constructed by credible rating agencies (Association for Investment Management and Research (AIMR)) Scores and Standard \& Poor's (S\&P) Transparency and Disclosure Scores, for instance), to mention a few. The self-constructed score was selected for measuring voluntary disclosure for two reasons: they have stated that selfconstructed scores are more trustworthy, and properly measure what they stand for (validity). Self-constructed rating scores are more successful than standard disclosure indices especially in cases where many questions are raised concerning the efficiency of externally designed measuring indices (e.g. whether this rating procedure is capable of properly measuring the changes in disclosure approaches taken by the company?). To extract voluntary disclosure index, this study employed a weighted disclosure index for measuring the disclosure score of each and every company; a disclosure index was developed to meet this end, composed of approximately 112 financial and 131 nonfinancial items [21].

Every individual item was assigned with a unique score, depending on the perceived importance, and weight and extent of disclosure by the company. These scores were mostly retrieved fromthe company's website and Board reports. Voluntary disclosure index can therefore be defined as:

VolDisc $_{j}=\frac{1}{n_{j}} \sum_{i=1}^{n_{j}} w_{i} d_{i}$

In which:

VolDisc $_{j}$ is the disclosure weight index for the company $j$, and $W_{i}$ represents the assigned weight to the informational item $i$, as disclosed by the company

1. j represents the assigned weight 
Citation: Ghasempour A, MdYusof MA (2014) The Effect of Fundamental Determinants on Voluntary Disclosure of Financial and Nonfinancial Information: The Case of Tehran Stock Exchange. J Account Mark 3: 108. doi: 10.4172/2168-9601.1000108

Page 4 of 6

2. Access to Growth Opportunities $(\mathrm{M} / \mathrm{B})=$ market/book ratio or price/earnings ratio $(\mathrm{P} / \mathrm{E})$

3. Leverage $=$ Total Average Debt $/$ Total Average Assets

4. Size $=$ natural logarithm of the company's total average stock market value;

5. Complexity: total receivables and inventory/total assets.

6. Firm Value: to calculate Tobin's Q, the model proposed by Perfect and Wiles (1994) was employed. Their proposed index follows:

$$
Q=\frac{M V(\text { Eqity })+B V(\text { Debt })}{B V(\text { Asset })}
$$

The ultimate proposed models for investigating the effects of company fundamentals on

Voluntarydisclosure was extracted as follows:

VolDisc $T=\alpha_{0}+\alpha_{1}$ Fvalue $+\alpha_{2}$ Size $+\alpha_{3} M / B+\alpha_{4}$ Leverage + $\alpha_{5}$ Complexity $+\alpha_{6} \mathrm{ROE}+\alpha_{7}$ EarnVol $+\psi$

VolDisc $1=\alpha_{0}+\alpha_{1}$ Fvalue $+\alpha_{2}$ Size $+\alpha_{3} M / B+\alpha_{4}$ Leverage + $\alpha_{5}$ Complexity $+\alpha_{6} \mathrm{ROE}+\alpha_{7}$ Earn Vol $+\psi$

VolDisc $2=\alpha_{0}+\alpha_{1}$ Fvalue $+\alpha_{2}$ Size $+\alpha_{3} M / B+\alpha_{4}$ Leverage + $\alpha_{5}$ Complexity $+\alpha_{6} R O E+\alpha_{7}$ EarnVol $+\psi$

\begin{tabular}{|c|c|c|c|c|c|}
\hline \multicolumn{7}{|c|}{ Descriptive Statistics of Research Variables } \\
\hline Variable & Mean & Median & Max & Min & Standard \\
\hline Business Complexity & 0.474 & 0.4597 & 3.757 & 0.029 & 0.327 \\
\hline Leverage & 0.661 & 0.672 & 1.093 & 0.186 & 0.168 \\
\hline Growth Opportunity (M/B) & 3.84 & 2.092 & 47.566 & 0.104 & 4.96 \\
\hline Size & 12.884 & 12.725 & 16.945 & 9.5 & 1.546 \\
\hline $\begin{array}{c}\text { Return on Equity } \\
\text { Secondary Disclosure Index } \\
\text { (VOLDISC1) }\end{array}$ & 0.61 & 0.407 & 5.672 & -1.177 & 0.733 \\
\hline $\begin{array}{c}\text { Secondary Disclosure Index } \\
\text { (VOLDISC2) }\end{array}$ & 14.687 & 12 & 110 & 0 & 13.883 \\
\hline $\begin{array}{c}\text { Secondary Disclosure Index } \\
\text { (VOLDISC3) }\end{array}$ & 29.57 & 16 & 260 & 0 & 38.128 \\
\hline $\begin{array}{c}\text { Secondary Disclosure Index } \\
\text { (VOLDISC4) }\end{array}$ & 6.744 & 3 & 57 & 0 & 9.624 \\
\hline $\begin{array}{c}\text { Secondary Disclosure Index } \\
\text { (VOLDISC5) }\end{array}$ & 5.798 & 3 & 43 & 0 & 6.262 \\
\hline $\begin{array}{c}\text { Secondary Disclosure Index } \\
\text { (VOLDISCT) }\end{array}$ & 151.361 & 126 & 646 & 13 & 105.255 \\
\hline
\end{tabular}

Table 1: Descriptive Statistics of Research Variables.

\begin{tabular}{|c|c|c|c|}
\hline Model & ModellT & Model1 & Model2 \\
\hline F-Stastics & 1.728 & 1.861 & 1.169 \\
\hline Prob>F & 0.0013 & 0.0003 & 0.2069 \\
\hline$\chi^{2}-$ Statistic & 116.919 & 124.691 & 0.0319 \\
\hline Pr ob $>\chi^{2}$ & 0.0001 & 0 & 86.523 \\
\hline Number of Observations & 573 & 573 & 573 \\
\hline Model Type & Panel & Panel & Mixed \\
\hline
\end{tabular}

Table 2: Panel or Mixed Model Identification(F-LimerTest).

\section{Research Findings}

\section{Descriptive analyses}

Table 1 shows the descriptive statistics of research variables. The values were obtained and analyzed using SPSS, Eviews, Stata, and Excel. Results from analyzing descriptive statistics revealed that the obtained scores for the total voluntary disclosure index fluctuated between 13 and 646. This high dispersion of scores indicates the absence of a unified approach among companies for information disclosure. Mean disclosure index score (VOLDISCT) was 126, with a standard deviation of 105.255. High standard deviation of the obtained scores is probably due to the major difference in firm sizes of companies enlisted on Tehran Stock Exchange. Furthermore, average obtained scores for secondary voluntary disclosure indices, namely, shareholder value creation (VOLDISC1), customers and products (VOLDISC2), intellectual capital and human resources (VOLDISC3), social and environmental reporting (VOLDISC4), and lastly corporate governance (VOLDISC5), were obtained at $94.598,14.687,29,570,6.744$, and 5.798, respectively, indicative of the fact that companies are more inclined to disclose the information pertaining to their financial performance and much less their nonfinancial information, especially that pertaining to their corporate governance and socio-environmental reporting.

\section{Normality test}

Since the analyses in this section are conducted using Dynamic PanelEstimator (GMM), data normality is not prioritized. Nevertheless, Jarque-Bera and Shapiro-Wilk tests were followed through for data normality, and cases of non-normality, were normalized using features of STATA software.

Step one: panel or mixed model identification (F-Limer test): Prior to model estimation, it needs to be identified that whether the model is with single or multiple y-intercepts, i.e. whether there is a panel or mixed distribution. F-Limer test was utilized to meet this end. Results of the mentioned tests for models pertaining to the first theory are presented in Table 2.

Here, the $\mathrm{H}_{0}$ implies non-panel distribution. As shown by the results, except for sub model 2 (Model2), the models maintain panel distribution. As stated above, panel data has singly y-intercept, while mixed data has multiple $y$-intercepts.

Step two: random effects test and hausman test: Having determined the type of $y$-intercept, the next issue to deal with is whether the discussed $y$-intercepts are fixed or random. From a theoretical point of view, if all the y-intercepts of the population are present, the model will be fixed effect model. It, however, should be kept in mind that in case the conditions justify random effect estimation theory, a Hausman Test needs to be conducted primarily, and if that rejects, fixed effect model is the correct procedure. The $\mathrm{H}_{0}$ of Hausman test proved that the model is a random effects model. The important point to be considered here is that the basis of Hausman test is that the test is required to be estimated randomly first, only then can the Hausman test be conducted. Results from the above tests for the first model are presented in Table 3.

As shown by the results, the main model as well as submodel 1 is required to be estimated as the random effects of $y$-intercepts.

Step three: heteroscedasticity test: One of the problems of regression model is the Heteroscedasticity of modeling errors, imposed by the violation of the hypothesis $\operatorname{Var}\left(U_{i}\right)=\sigma^{2} I$. Such an issue in the regression will cause the OLS result to be no longer efficient. The $\mathrm{H}_{0}$ is Homoscedasticity. 


\begin{tabular}{|c|c|c|c|}
\hline Model & ModelT & Model1 & Model2 \\
\hline Wald chi2 $(7)$ & 9.167 & 8.532 & - \\
\hline Prob> chi2 & 0.241 & 0.288 & - \\
\hline Final Result & Random Effects & Random Effects & \\
\hline
\end{tabular}

Table 3: Random Effects and Hausman Tests for the Research Models.

\begin{tabular}{|c|c|c|c|}
\hline Model & ModelT & Model1 & Model2 \\
\hline \multirow{2}{*}{$y$-intercept } & 3.222 & 3.024 & 0.813 \\
\hline & $(9.351)^{\star \star \star}$ & $(9.912)^{\star \star \star}$ & -1.624 \\
\hline \multirow{2}{*}{$\begin{array}{l}\text { Access to Growth } \\
\text { Opportunities }\end{array}$} & -0.189 & -0.130 & -0.449 \\
\hline & $(-2.505)^{\star * *}$ & $(-1.921)^{\star \star}$ & $(-3.167)^{\star \star \star}$ \\
\hline \multirow{2}{*}{ Size } & 0.135 & 0.097 & 0.291 \\
\hline & $(2.958)^{\star * *}$ & $(2.402)^{\star \star \star}$ & $(4.471)^{\star * *}$ \\
\hline \multirow{2}{*}{ Financial Leverage } & 0.169 & 0.069 & 0.183 \\
\hline & $(1.483)$ & $(0.671)$ & $(1.114)$ \\
\hline \multirow{2}{*}{ Complexity of Business } & 0.134 & 0.141 & 0.175 \\
\hline & $(2.746)^{\star \star \star}$ & $(3.246)^{\star \star \star}$ & $(2.665)^{*}$ \\
\hline \multirow{2}{*}{ Financial Performance } & 0.012 & 0.009 & 0.037 \\
\hline & $(0.330)$ & $(0.287)$ & $(0.725)$ \\
\hline \multirow{2}{*}{ Earnigs Volatility } & 0.009 & 0.029 & -0.123 \\
\hline & $(0.267)$ & $(0.914)$ & $(-2.432)^{\star *}$ \\
\hline \multirow{2}{*}{ Firm value in the Past Year } & 0.014 & 0.111 & 0.230 \\
\hline & $(0.206)$ & $(1.823)$ & $(2.474)$ \\
\hline \multirow{2}{*}{$\mathrm{AR}(1)$} & - & - & 0.202 \\
\hline & & & $(3.416)$ \\
\hline Adj_R2 & 0.065 & 0.076 & 0.098 \\
\hline $\mathrm{F}$ & 4.660 & 5.238 & 4.778 \\
\hline Prob>chi2 & 0.000 & 0.000 & 0.000 \\
\hline D.W. & 1.700 & 1.87 & 1.84 \\
\hline Number of Observations & 366 & 356 & 278 \\
\hline
\end{tabular}

${ }^{* * *},{ }^{* *}$, and ${ }^{*}$ indicate significant at $1 \%, 5 \%$, and $10 \%$ respectively

Table 4: Final Estimate of Regressive Models.

Generalized least squares were adopted for cases of approved Heteroscedasticity.

Step four: autocorrelation test: Another recurrent problem in a regression model is autocorrelation between the residuals. Autocorrelation is violation of one of the standard assumptions of the regression model (the assumption: $\operatorname{COV}\left(\mathrm{u}_{\mathrm{i}}, \mathrm{u}_{\mathrm{i}}\right)=0$. The OLS estimation technique, thus, loses the Best Linear UnbiasedEstimator (BLE) feature, and as a result, the statistical inference would render unreliable. The autocorrelation problem can exist as first order Autoregressive Process $(\mathrm{AR}(1))$, higher orders, or Moving Average Process (MA(q)). The $\mathrm{H}_{0}$ here is the absence of autocorrelation. In cases observed with first order autocorrelation, coefficient estimates such as $\mathrm{AR}(1)$ were used to obviate autocorrelation.

Step five: final estimate of regressive models: The final model is consequently estimated in the final step subsequent to diagnostics. Results of model estimates are given in Table 4. As observable from the results depicted in Table 4, the t-statistics pertaining to the variables of firm size and complexity of business have significant and positive relationship with the voluntary disclosure levels of financial and nonfinancial information at the significance level of 0.05 in all the three models. The mentioned statistics for the same variables is 2.958 and 2.746 in the main model respectively. In other words, the results show that larger corporations and companies with higher business complexity are more inclined to disclose their information, probably due to the fact that they are interested to ensure their shareholders that the company's resources are properly managed and administered by the company.
Imposed pressures on behalf of the government, other organizations, and media can also be regarded as contributing factors. The negative coefficient of access to growth opportunities, on the other hand, implies that the company may have access to a range of opportunities for possible sales promotion, and is reluctant to further disclose pertinent information to maintain its competitive edge. The t-statistics of this variable is -2.505 in the main model. In contrast, according to Table 4 , there is no significant relationship between variables of financial leverage, financial performance (profitability), and earnings volatility and voluntary disclosure, i.e. desirable financial conditions does not necessarily trigger higher information disclosure, and possibly other leverages are the contributing factors in this case.

\section{Discussion and Conclusion}

This study investigated voluntary reporting of companies concerning two divisions of financial and nonfinancial information and analyzed the effects of company fundamentals on such reporting. Results from hypothesis testing maintained that the variables of firm size and complexity of business have significant and positive relationship with the voluntary disclosurelevels of financial and nonfinancial information, as evidences to the point that larger corporations and also companies with higher business complexity are more inclined to disclose their information, probably due to the fact that they are interested to ensure their shareholders of the proper management of the company's resources. Pressures from the government, other organizations, and the media can also be regarded as additional contributing factors. The negative coefficient of access to growth opportunities, on the other hand, implies that the company may have access to a range of opportunities for possible sales promotion, and is reluctant to further disclose pertinent information to maintain competitive edge. Furthermore, there is no significant relationship between variables of financial leverage, financial performance (profitability), and earnings volatility and voluntary disclosure, i.e. desirable financial conditions does not necessarily trigger higher information disclosure, and possibly other leverages are the contributing factors.

Accordingly, most of the research hypotheses, except for the two variables of financial performance and earnings volatility, are proven at the significance level of 0.05 . Findings of the present study in terms of the majority of the variables are consistent with similar studies conducted in other countries [6-12].

The results of the present study suggest that in their investment decisions, analyzers should take into account voluntary disclosure. It is also suggested that Tehran Stock Market devises incentives for smaller companies to further encourage voluntary disclosure.

\section{References}

1. Verrecchia R (1983) Discretionary disclosure. Journal of Accounting \& Economics 5: 179-1948uality and the Cost of Debt, The Accounting Review 73: $459-474$

2. Chtourou SM, Bedard J, Courteau L (2001) Corporate governance and earnings management. Working Paper, Universite Laval, Canada.

3. KleinA (2002) Audit committee, board of director characteristics, and earnings management. Journal of Accounting and Economics. 33: 375-400.

4. Peasnell KV, Pope PF, Young SE (2001) The characteristics of firms subject to adverse rulings by the financial reporting review panel. Accounting and Business Research. 31: 291-311.

5. Xie B, Davidson WN, DaDalt PJ (2001) Earnings management and corporate governance: the roles of the board and the audit committee, Journal of Corporate Finance 9: 295-316. 
Citation: Ghasempour A, MdYusof MA (2014) The Effect of Fundamental Determinants on Voluntary Disclosure of Financial and Nonfinancial Information: The Case of Tehran Stock Exchange. J Account Mark 3: 108. doi: 10.4172/2168-9601.1000108

6. Beekes $W$, Pope P, Young S (2004) The link between earnings conservatism and board composition: Evidence from the U.K. An International Review, 12: 47-59.

7. Eng LL, Mak YT (2003) Corporate governance and voluntary disclosure,Journal of Accounting and Public Policy, 22: 325-345..

8. Yazdi HK, Hemmati K, BayatA (2012) The Assessment of Social Reporting on behalf of Accepted Corporations Listed in Tehran Stock Exchange, Business Intelligence Journal (BIJ),5: 214-223.

9. SajadiH, Mansour Z, Alireza J (2009) Nonfinancial characteristics effective on financial disclosure quality in Tehran Exchange market listed companies, Accounting and Auditing Assessments Journal 16: 51-68.

10. ForoughiD, Morteza M, ShahshaniS, Poorhossein (2008) Directors attitude towards disclosure of social information: Stock Market listed companies (2007), Accounting and Auditing Assessments Journal 15: 55-70
11. Kashanipoor, Mohammad, Ali Rahmani, and Parchini (2009) The relationship between voluntary disclosure and non-executive directors, Accounting and Auditing Assessments Journal 16: 85-100.

12. O'DwyerB (2002) Managerial Perceptions of Corporate Social Disclosure: An Irish Story, Accounting Auditing and Accountability Journal 15: 406-436.

13. DeeganC, RankinM, Tobin J (2002) An Examination of the Corporate Social and Environmental Disclosures of BHP from 1983-1997: A Test of Legitimacy Theory". Accounting, Auditing \& Accountability Journal15: 312-343.

14. Franncis F, Nanda D, Olsson A (2008) Voluntary Disclosure, Earnings Quality, and Cost of Capital", Journal of Accounting Research 46: 53-99.

15. BayatAli (2012)The relationship between the levels of voluntary disclosure, the cognitive styles of decision-making, and information asymmetry: according to Stakeholder Theory,Ph.D. Dissertation in Accounting, Islamic Azad University, Science and Research Branch, Faculty of Management and Economics. 